\author{
Н. Ісаєва, \\ аспірант \\ Дніпропетровського державного університету внутрішніх справ
}

\title{
ТЕОРЕТИКО-ПРАВОВА ХАРАКТЕРИСТИКА КУЛЬТУРНИХ ПРАВ ВНУТРІШНЬО ПЕРЕМІЩЕНИХ ОСІБ: МЕТОДОЛОГІЧНІ АСПЕКТИ ТА ПРАКТИЧНІ ЗАСАДИ
}

Українське суспільство сьогодні живе в часи швидких змін. Змінюється держава, суспільство та взаємини людей особливо в період збройного конфлікту, що триває на території України з 2014 року. Однак незмінним пріоритетом будь-якої держави, у тому числі й України, є забезпечення прав людини та громадянина, незважаючи на те, у якому куточку країни та за яких обставин опинилася людина. Важливим напрямом у забезпеченні культурних прав людини в Україні є ефективна реалізація таких прав внутрішньо переміщеними особами. Це питання є актуальним у житті кожної людини.

На законодавчому рівні декларовані культурні права та свободи внутрішньо переміщених осіб реально не дотримуються, колізії та прогалини в чинному законодавстві продовжують чинити перешкоди для повноцінної реалізації внутрішньо переміщеними особами своїх конституційних прав і свобод. Так, звичайний громадянин України та внутрішньо переміщені особи мають неоднаковий доступ до ресурсів держави. Інтеграція Украіни до Європейського Союзу вимагає переосмислення такої ситуації та відтворення рівного доступу всіх громадян України до своїх культурних прав, незважаючи на статус «внутрішньо переміщена особа».

Підгрунтям для таких висновків є стан забезпечення в Україні культурних прав і свобод внутрішньо переміщених осіб і гарантій їх реалізації.
Важливий внесок у дослідження цього питання в різних його аспектах зробили такі вітчизняні та зарубіжні науковці, як I. Алімова, Н. Бортник, Н. Грабар, М. Менджул, М. Мацькевич, T. Проценко, А. Пшенична, О. Рогач, М. Савчина, О. Цельєв, I. Хомишина та інші. Авторський аналіз публікацій свідчить, що дотримання культурних прав і свобод внутрішньо переміщених осіб в Україні ще не набуло комплексного та грунтовного вивчення.

Дотримання й захист культурних прав внутрішньо переміщених осіб і гарантій їх реалізації є одними з першочергових завдань сучасної правової та демократичної держави. Саме тому актуальність дослідження зумовлена наявністю таких основних протиріч між об’єктивною необхідністю підвищення якості й ефективності нормативно-правового регулювання в умовах сучасного ситуативного простору та недооцінкою ролі державних інституцій, діяльність яких спрямована на забезпечення урегулювання нагальної потреби реалізації своїх культурних прав внутрішньо переміщеними особами; необхідністю впровадження дієвого інструментарію у сфері усунення таких протиріч і відсутністю теоретико-методологічних засад його формування.

Метою статті $€$ системний аналіз забезпечення культурних прав і свобод внутрішньо переміщених осіб в Україні, а також унесення власних пропозицій щодо вдосконалення правового забез- 
печення реалізації останніх у національному законодавстві.

У сучасній парадигмі розвитку суспільства саме культура розглядається як джерело, що стимулює соціально-економічний прогрес як чинник, що зумовлює та забезпечує нову якість життя як засіб забезпечення національного духу. Право людини на розвиток і реалізацію своїх творчих здібностей, доступ до культурних надбань і практик, збереження культурно-історичної спадщини визначається як культурне право людини. Культурні права забезпечують духовний розвиток особистості Й суспільства, який у певному розумінні $€$ найважливішою умовою ствердження в країні демократії та прав людини [1, с. 81-85].

Права, свободи й обов'язки людини та громадянина є центральним елементом, основою конституційно-правового статусу особи. Саме в правах, свободах та обов'язках юридично оформляються стандарти поведінки громадянина, що визнаються й гарантуються державою. Закріплення в Конституціі, інших актах чинного законодавства прав і свобод людини та громадянина, їх обсяг, види та зміст нині є однією $з$ пріоритетних проблем цивілізації. Водночас становлення й розвиток таких прав - суттєва ознака ступеня демократизації всіх політичних і суспільних інститутів, зрілості громадянського суспільства, показник, що характеризує певну державу як правову чи навпаки [2, с. 16]. Саме тому багаторазове порушення культурних прав внутрішньо переміщених осіб, включаючи дискримінацію, i проблеми, що виникають у доступі та здійсненні їхніх прав у результаті переміщення, є актуальними сьогодні в Україні.

Нині законодавчо культурні права в Україні врегульовано Конституцією України, Законом України «Про Українький культурний фонд», Законом України «Про дошкільну освіту», Законом України «Про освіту», Законом України «Про вищу освіту», Законом України «Про наукову i науково-тех- нічну діяльність», Законом України «Про забезпечення прав і свобод внутрішньо переміщених осіб», Законом України «Про позашкільну освіту», Законом України «Про охорону дитинства», Законом України «Про повну загальну середню освіту», Законом України «Про професійну (професійно-технічну) освіту», Законом України «Про національні меншини в Україні», Законом України «Про культуру», Законом України «Про державну підтримку кінематографії в Україні», Законом України «Про Український культурний фонд», Законом України «Про авторське право і суміжні права», Законом України «Про бібліотеки та бібліотечну справу», Законом України «Про музеї та музейну справу», Законом України «Про вивезення, ввезення та повернення культурних цінностей, Законом України «Про запобігання фінансової катастрофи та створення передумов для економічного зростання в Україні, Законом України «Про засади мовної державної політики», Законом України «Про театри та театральну справу», Законом України «Про державні соціальні стандарти та державні соціальні гарантії», Законом України «Про державні соціальні стандарти та державні соціальні гарантії, Постановою Кабінету Міністрів України «Про Єдиний державний реєстр осіб, які мають право на пільги» від 29 січня 2003 року № 117, Розпорядженням Кабінету Міністрів України «Про схвалення Довгострокової стратегії розвитку української культури - стратегії реформ» від 1 лютого 2016 року № 119-р, Наказом Міністерства культури України «Про реалізацію права соціально незахищених верств населення на відвідування підприємств, установ та організацій, які належать до сфери управління Мінкультури України, на пільгових умовах» від 30 січня 2013 року № 43 тощо.

Фізична особа має право на збереження своєї національної, культурної, релігійної, мовної самобутності, а також право на вільний вибір форм і способів прояву своєї індивідуальності, якщо 
вони не заборонені законом і не суперечать моральним засадам суспільства [3].

Унаслідок свого переміщення внутрішньо переміщені особи втрачають доступ до освіти. Навіть після повернення у свої домівки останні можуть не мати доступу до освіти, оскільки іхні школи можуть бути знищені чи не працювати через інші причини. Проте доступ до освіти є основоположним для розвитку внутрішньо переміщених осіб, особливо для переміщених дітей, оскільки він забезпечує необхідне підгрунтя для подальшого працевлаштування чи уникнення економічної або сексуальної експлуатації в майбутньому [4, с. 226].

Законом України «Про культуру» визначено організаційно-правові засади розвитку культури в України, збереження культурної спадщини та забезпечення доступу до культурних цінностей на території країни. Також серед основних засад державної політики у сфері культури визначено забезпечення свободи творчості, захист прав інтелектуальної власності, авторського права й суміжних прав; гарантування прав громадян у сфері культури; створення умов для творчого розвитку особистості, підвищення культурного рівня, естетичного виховання громадян, доступності освіти у сфері культури для дітей і юнацтва, задоволення культурних потреб Українського народу, розвитку закладів культури незалежно від форми власності, залучення до сфери культури інвестицій, коштів від надання платних послуг, благодійництва, інших не заборонених законодавством джерел; захист і збереження культурної спадщини як основи національної культури, турбота про розвиток культури; сприяння утвердженню гуманістичних ідей, високих моральних засад у суспільному житті [5]. Безумовно, усі напрями державної політики у сфері культури є важливими, однак, ураховуючи той факт, що певні території України є тимчасово окупованими та є збройний конфлікт, збереження культурної спадщини як основи національної культури та спри- яння утвердженню гуманістичних ідей, високих моральних засад у суспільному житті $€$ актуальним сьогодні. Внутрішньо переміщені особи зіткнулися з багатьма проблемами у сфері захисту культурних прав на території інших громад.

Українська держава гарантує всім народам, національним групам, громадянам, які проживають на їі території, рівні політичні, економічні, соціальні та культурні права [6].

Культурні права включають той аспект, що навчальні заклади й інші освітні простори повинні бути безпечними, щоб не піддавати дітей і підлітків внутрішньо переміщених осіб насильству, експлуатації та іншим ризикам. Це й школи та їх будівлі, включаючи туалети, безпечні, гендерно-чутливі для дітей; весь персонал навчальних закладів, як національний, так і міжнародний, має гідні умови праці, поважає кодекс поведінки й отримує базову підготовку з таких тем, як методологія навчання, права людини, запобігання сексуальному насильству та експлуатації, психосоціальна підтримка, позитивна дисципліна, систематично їх підвищує; навчальна програма та методика викладання спрямовані на сприяння миру, примирення та конструктивний діалог, включаючи навчання життєвих навичок; студенти інформуються про свої права (та обов'язки), ознайомлюються 3 наявними механізмами моніторингу й направлення, а також кодексу поведінки, що регулює роботу викладачів та інший педагогічний персонал; батьки й будь-які асоціації батьків-учителів беруть участь у збереженні своїх дітей i моніторингу безпеки навчальних просторів [7]. Відповідно до Постанови Кабінету Міністрів України «Про затвердження Порядку створення, ведення та доступу до відомостей Єдиної інформаційної бази даних про внутрішньо перемішених осіб» від 22 вересня 2016 року № 646, за формування та ведення бази даних відповідальним $€$ Міністерство соціальної політики України. 3 метою отримання інформації щодо кількості внутріш- 
ньо переміщених осіб, які навчаються в дошкільних, загальних середніх, професійно-технічних, навчальних закладах, закладах фахової передвищої освіти й вищих навчальних закладах, автором зроблено запит до Міністерства соціальної політики України. Однак указане Міністерство самостійно не обробило вищевказаний запит, а надіслало його до Міністерства освіти і науки Украіни. У свою чергу, Міністерство освіти і науки України Листом від 3 березня 2020 року № 4/1044-20 повідомило, що вони не $є$ адміністратором такої бази та не володіють указаною інформацією. За таких обставин сьогодні не визначено механізм обліку внутрішньо переміщених осіб, які навчаються в навчальних закладах, а отже, відсутній механізм оцінювання освітніх і культурних потреб внутрішньо переміщених осіб і їніх дітей.

Отже, пропонуємо внести зміни до абзацу 2 пункту 2 Постанови Кабінету Міністрів України «Про затвердження Порядку створення, ведення та доступу до відомостей Єдиної інформаційної бази даних про внутрішньо переміщених осіб» від 22 вересня 2016 року № 646, виклавши його так: «Відповідальним за забезпечення формування та ведення бази даних $€$ Мінсоцполітики та Міністерство освіти і науки України».

Пункт 4 Постанови Кабінету Міністрів України «Про затвердження Порядку створення, ведення та доступу до відомостей Єдиної інформаційної бази даних про внутрішньо переміщених осіб» від 22 вересня 2016 року № 646 потрібно доповнити таким змістом: «відомості щодо навчання внутрішньо переміщеною особою (дитиною) в навчальних закладах України та за ii межами будь-якої форми власності вносяться Міністерством освіти і науки України до бази даних з метою обліку відповідної інформації.

Нині існує інформація від Освітнього центру «Донбас - Україна» щодо кількості внутрішньо переміщених осіб, які вступили до закладів вищої та фахової перед вищої освіти й тільки з 2016 року: 2016 року - 855 внутрішньо переміщених осіб, 2017 року 1346, 2018 року - 1522, 2019 року $1600[8]$.

Інформація від освітнього центру «Крим - Україна» наявна також із 2016 року та виглядає так: 2016 року 153 особи, 2017 року - 204 особи, 2018 року - 254 особи та 2019 року 265 осіб [9].

Освіта також важлива для інтеграції внутрішньо переміщених осіб у суспільство, вона дає їм змогу розвинути громадянську свідомість і зменшити свою залежність від держави [10].

3 кожним роком кількість внутрішньо переміщених осіб, які вступають до вищих навчальних закладів і закладів фахової передвищої освіти України, стає більшою, однак, по-перше, така інформація не обліковується державою, а по-друге, наявна тільки щодо певної категорії закладів освіти й відсутня зовсім щодо дошкільних, загальних і професійно-технічних навчальних закладів.

Також сьогодні відсутня інформація щодо навчання та кількості внутрішньо переміщених осіб, їх обліку, які мають певні вади й навчаються в навчальних закладах України.

Такі прогалини в законодавстві унеможливлюють передусім дотримання державою гарантій щодо навчання внутрішньо переміщених осіб і їх облік 3 метою якісного надання освітніх послуг і повноцінної реалізації вказаною категорією осіб своїх конституційних прав і свобод.

Нікому не може бути відмовлено в праві на освіту. Держава під час виконання будь-яких функцій, узятих нею на себе в галузі освіти й навчання, поважає право батьків забезпечувати таку освіту й навчання відповідно до своїх релігійних і світоглядних переконань [11].

Розвиток сфери культури протягом тривалого часу не був визначений пріоритетом державної політики, йому не приділялася належна увага та не надавалася підтримка з боку державної 
влади. Такий підхід спричинив значною мірою виникнення негативних явищ і конфліктів в українському суспільстві, зокрема збройного протистояння, що призвело до тисяч загиблих і скалічених людей, понівечених доль і відібраних можливостей [12] Внутрішньо переміщеним особам саме на тлі збройного конфлікту довелося переміщатися в межах державного кордону задля безпеки свого життя й життя своїх близьких. I така категорія осіб потребує уваги щодо захисту своїх культурних прав передусім.

У нашій державі вже існує достатній законотворчий доробок у сфері гарантування, захисту й охорони культурних прав людини та громадянина, проте ще не спостерігається практичної реалізації задекларованих положень у діяльності державних органів влади та їх посадових осіб. Україна має обрати запропонований міжнародною спільнотою шлях, спрямований не лише на декларування принципу гарантування й дотримання культурних прав особи та всіх без винятку їх різновидів, а й здійснення важливих перспективних кроків щодо практичної реалізації визначених на найвищому конституційному й законодавчому рівнях правових положень і вимог [13, с. 95-97].

Конституційні культурні права й свободи людини та громадянина стосуються реалізації прав і свобод суб'єктів у культурній і духовній сферах. Розвиток культури особи й народу загалом значною мірою залежить саме від наданих державою можливостей розвивати, задовольняти та втілювати в життя свої культурні потреби. Регламентація конституційних культурних прав і свобод людини та громадянина в сучасній Україні здійснюється на трьох взаємодоповнюючих нормативних рівнях: конституційному, законодавчому та міжнародному [14, с. 20]. Перед Україною став виклик, як і перед іншими державами, котрі зіткнулися 3 вимушеним переселенням осіб у межах країни, розробити, доопрацювати й удосконалити національне законодавство 3 метою захисту внутрішньо переміщених осіб на всіх рівнях у межах країни та приведення до відповідності такого захисту міжнародним стандартам.

Грунтовний аналіз дослідження взаємозв'язку державних органів у здійсненні обліку внутрішньо переміщених осіб і їніх дітей, адміністрування Єдиної інформаційної бази даних про внутрішньо переміщених осіб, обліку культурних та освітніх потреб такої категорії осіб дає змогу стверджувати, що запропоновані автором зміни до чинного законодавства України є нагальною необхідністю правової держави й дієвим механізмом виявлення потреб i забезпечення культурних прав внутрішньо переміщених осіб і їхніх дітей.

У статті проаналізовано стан забезпечення культурних прав внутрішньо переміщених осіб в Україні. Визначено об'єктивну необхідність підвищення якості й ефективності нормативно-правового регулювання в умовах сучасного ситуативного простору та недооиінку ролі державних інституиій, діяльність яких спрямована на забезпечення врегулювання нагальної потреби реалізації своїх культурних прав внутрішньо переміщеними особами. На законодавчому рівні декларовані культурні права та свободи внутрішньо переміщених осіб реально не дотримуються, колізії й прогалини в чинному законодавстві чинить перешкоди для повноцінної реалізацї внутрішньо переміщеними особами своїх конституційних прав $і$ свобод. Так, звичайний громадянин України та внутрішньо переміщені особи мають неоднаковий доступ до ресурсів держави. Проведено системний аналіз дотримання культурних прав $і$ свобод внутрішньо переміщених осіб в Україні, а також акцентовано увагу на необхідності вдосконалення взаємодії державних інституиій з метою урегулювання нагальної потреби реалізацї культурних прав внутрішньо переміщеними особами. Акцен- 
товано, що перед Україною став виклик, як $і$ перед іншими державами, котрі зіткнулися з вимушеним переселенням осіб у межах країни, розробити, доопрацюювати й удосконалити національне законодавство з метою захисту внутрішньо переміщених осіб на всіх рівнях у межах країни та приведення до відповідності такого захисту міннародним стандартам. 3 метою якісного обліку й виявлення культурних потреб внутрішньо переміщених осіб запропоновано авторські зміни до порядку адміністрування Єәиної інформаційної бази даних про внутрішньо перемімених осіб $i$ внесення необхідної інформації для обліку та виявлення освітніх потреб внутрішньо переміщених осіб $i$ їніх дітей. Iнтеграизія Украйни до Европейського Союзу вимагає переосмислення такої ситуації та відтворення рівного доступу всіх громадян України до своїх культурних прав, незважаючи на статус «внутрішньо переміщена особа». У цьому контексті в Україні особливої актуальності набуває питання гарантування державою реалізаціі культурних прав внутрішньо переміщеними особами.

Ключові слова: демократія, культурні права, право на освіту, права людини, внутрішньо переміщена особа, діти, освіта, культура.

Isayeva N. Theoretical-legal characteristics of cultural rights of internally displaced persons: methodological aspects and practical background

The article analyzes the status of cultural rights of internally displaced persons in Ukraine. The objective necessity of improving the quality and effectiveness of regulatory regulation in the context of the current situational space and underestimating the role of state institutions aimed at ensuring the urgent need to exercise their cultural rights by internally displaced persons have been determined. At the legislative level, the declared cultural rights and freedoms of internally displaced persons are not actually respected, and conflicts and loopholes in the current legislation continue to impede the full exercise of their constitutional rights and freedoms by internally displaced persons. The ordinary citizen of Ukraine and internally displaced persons has unequal access to state resources. Analysis of the observance of cultural rights and freedoms of internally displaced persons in Ukraine was conducted, and the emphasis was placed on the need to improve the interaction of state institutions in order to address the urgent need for the exercise of cultural rights by internally displaced persons. It is emphasized that Ukraine has been challenged, as well as other countries, which have been faced with forced displacement of persons within the country, to develop, refine and improve national legislation in order to protect internally displaced persons at all levels within the country and to comply with such protection to international standards. In order to qualitatively account and identify the cultural needs of internally displaced persons, copyright changes have been proposed to the order of administration of the Unified Information Database on Internally Displaced Persons and to enter the necessary information to account for and identify the educational needs of internally displaced persons and their children. The integration of Ukraine into the European Union requires a rethinking of this situation and the restoration of equal access for all citizens of Ukraine to their cultural rights, regardless of the status of "internally displaced person". In this context, the issue of guaranteeing the state the realization of cultural rights by internally displaced persons is of particular relevance in Ukraine.

Key words: democracy, cultural rights, right to education, human rights, internally displaced person, children, education, culture. 


\section{Література}

1. Іенатченко І.Г. Особливості реалізаизї прав і свобод людини у сфері культури в Україні. Правові засади гарантування та захисту прав $і$ свобод людини $i$ громадянина : збірник наук. статей $i$ тез наук. повід. за матеріалами Міжнар. наук.-практ. конф., м. Полтава, 23 листопада 2012 р. Харків : Точка, 2012. 4. 1. С. 81-85.

2. Конституиійні права, свободи $i$ обов'язки людини і громадянина в Україні : монографія / за ред. Ю.С. Шемшученка. Київ : Юридична думка, 2008. 252 с.

3. Цивільний кодекс України : Закон України від 16 січня 2003 року (зі змінами $i$ допов.). URL: https://zakon.rada.gov.ua/ laws / show/435-15.

4. Rhodri C. Williams. Protecting Internally Displaced Persons: A Manual for Law and Policymakers. Washington : Brookings Institution - University of Bern, 2008. 288 p.

5. Про культуру : Закон України від 14 грудня 2010 року (зі змінами $і$ допов.). URL: https: / / zakon.rada.gov.ua/laws / show / 2778-17.

6. Декларація прав національностей України від 01.11.1991. URL: https:// zakon.rada.gov.ua/laws/show/1771-12.
7. Hand book for the Protection of Internally Displaced Persons. 2010. URL: https: / / www.unhcr.org / 4c2355229.pdf.

8. Лист МОНУ від 13.03.2020 № 6 / 450-20.

9. ЛистМОНУвід03.03.2020 №4 / 1044-20.

10. Організаиія освіти для біжениів i внутрішньо переміщених осіб : Рекомендація ПАРЕ від 2 березня 2004 року № 1652 (2004).

11. Протокол до Конвенції про захист прав людини $i$ основоположних свобод : Протокол Ради Європи від 20.03.1952. URL: https: / / zakon.rada.gov.ua/laws / show /994_535.

12. Про схвалення Довгострокової стратегіїрозвитку українськоїкультури-стратегіi реформ : Розпорядження Кабінету Міністрів України від 01.02.2016 № 119-p. URL: https: / / zakon.rada.gov.ua/laws / show / 119-2016-\% D1\%80.

13. Строган А.Ю. Культурні права особи в національних та міжнародних нормативно-правових актах: порівняльний аналіз. Економіка та держава. 2008. № 8. C. 95-97.

14. Мацькевич М. Культурні права та свободи людини $i$ громадянина: питання регламентації змісту та реалізації. Віче. 2011. № 20. C. 20. 